\title{
Association study of functional genetic variants of innate immunity related genes in celiac disease
}

\author{
B Rueda1 , A Zhernakova ${ }^{2}$, MA López-Nevot ${ }^{3}$, J Martín ${ }^{1}$ and BPC Koeleman*2
}

\begin{abstract}
Address: ${ }^{1}$ Instituto de Parasitología y Biomedicina "López-Neyra", CSIC, Granada, Spain, ${ }^{2}$ Complex Genetics Group, Department of Biomedical Genetics, University Medical Center, Utrecht, The Netherlands and '3Servicio de Inmunología, Hospital Virgen de las Nieves, Granada, Spain

Email: B Rueda - blarume@ipb.csic.es; A Zhernakova - a.zhernakova@med.uu.nl; MA López-

Nevot - miguel.lopez.nevot.sspa@juntadeandalucia.es; J Martín - martin@ipb.csic.es; BPC Koeleman* - b.p.c.koeleman@med.uu.nl

* Corresponding author
\end{abstract}

Published: 03 August 2005

BMC Medical Genetics 2005, 6:29 doi:10.1 I86/147/-2350-6-29

This article is available from: http://www.biomedcentral.com/I47/-2350/6/29

(C) 2005 Rueda et al; licensee BioMed Central Ltd.

This is an Open Access article distributed under the terms of the Creative Commons Attribution License (http://creativecommons.org/licenses/by/2.0), which permits unrestricted use, distribution, and reproduction in any medium, provided the original work is properly cited.
Received: 29 March 2005

Accepted: 03 August 2005

\begin{abstract}
Background: Recent evidence suggest that the innate immune system is implicated in the early events of celiac disease (CD) pathogenesis. In this work for the first time we have assessed the relevance of different proinflammatory mediators typically related to innate immunity in $C D$ predisposition.

Methods: We performed a familial study in which 105 celiac families characterized by the presence of an affected child with CD were genotyped for functional polymorphisms located at regulatory regions of IL-I $\alpha$, IL-I $\beta$, IL-IRN, IL-I8, RANTES and MCP-I genes. Familial data was analysed with a transmission disequilibrium test (TDT) that revealed no statistically significant differences in the transmission pattern of the different genetic markers considered.
\end{abstract}

Results: The TDT analysis for IL-I $\alpha$, IL-I $\beta$, IL-IRN, IL-I 8, and MCP-I genes genetic variants did not reveal biased transmission to the affected offspring. Only a borderline association of RANTES promoter genetic variants with CD predisposition was observed.

Conclusion: Our results suggest that the analysed polymorphisms of IL-I $\alpha$, IL-I $\beta$, IL-IRN, IL-I8, RANTES and MCP-I genes do not seem to play a major role in CD genetic predisposition in our population.

\section{Background}

Celiac disease (CD) is an autoimmune disorder of the small intestine in which dietary gluten ingestion leads to a chronic inflammatory status of the mucosa [1]. There is strong evidence for a genetic component for CD, with the HLA genes being the strongest genetic locus associated with CD predisposition known to date. About 95\% of CD patients are carriers of the DQ2 molecule, encoded by DQA $1 * 05 / \mathrm{DQB} 1 * 02$ alleles, compared to $\sim 10 \%$ of healthy control subjects. Furthermore, the DQ8 molecule (DQA $1 * 0301 / \mathrm{DQB} 1 * 0302$ is also found more frequently in CD patients although to a lesser extent [2]. Finally, a role for genes located outside the HLA region has been suggested since the overall contribution of HLA genes to CD genetic predisposition is no more than $40 \%$ [1].

T CD4+ lymphocytes are key elements in the induction and progression of CD pathogenesis. Certain gluten peptides bound to DQ2 or DQ8 molecules cause proliferation and production of proinflammatory cytokines by lamina propria CD $4+\mathrm{T}$ cells [3]. Besides this activation of adaptive immune response, recent evidences suggest that 
there is an implication of the innate immunity in the initial phases of CD [4]. In this regard, some gluten peptides have been demonstrated to drive a danger signal that leads to an activation of the innate immune system $[5,6]$ and additionally it is thought that bacteria may play a role in $\mathrm{CD}$ [7]. In fact, $\mathrm{CD}$ patients show an up-regulation in the expression of pro-inflammatory cytokines typically related to the innate immune response, such us IL1, IL-18 and chemokines $[6,8-10]$.

The IL1 gene cluster located in the chromosomal region $2 q 12-22$ codifies for three proteins: IL-1 $\alpha$, IL-1 $\beta$ and IL-1 receptor agonist (IL-1RN), of which the two first are strong inducers of inflammation while IL-1RN is an effective antagonist binding to the IL-1 receptor without activating the target cell [11]. These genes are polymorphic bearing well-characterized single nucleotide polymorphisms (SNPs). Polymorphisms in IL-1 $\alpha$ at position -889 $\mathrm{C} / \mathrm{T}$ (rs1800587) and IL-1 $\beta$ at position $-511 \mathrm{C} / \mathrm{T}$ (rs1143627) were described $[12,13]$. Furthermore, recent findings showed that the $-511 \mathrm{C} / \mathrm{T}$ IL- $1 \beta$ genetic variant is related to differences in IL-1 $\beta$ protein secretion [14]. The $I L-1 R N$ gene contains within its second intron a variable number of an 86-bp tandem repeats (rs380092) [15], showing the allele 2 (IL-1RN*2; two repeats) an increased frequency in a variety of autoimmune and inflammatory disorders [16].

Another important member of the proinflammatory IL-1 family is IL-18, which is thought to be a key regulator of cytokine expression [17]. Furthermore, a role for IL-18 in the induction of an anti-gluten inflammatory response has been suggested $[10,18,19]$. It is thought that IL-18 gene variation in the promoter region regulates the expression of this cytokine [20]. Interestingly, in the IL-18 promoter region two SNPs -607 A/C (rs1946518) and -137 G/C (rs187238) were described, which are supposed to alter the IL-18 promoter activity [21].

Moreover, raised levels of chemokines such us RANTES (regulated upon activation, normal T-cells expressed and secreted) and monocyte chemoatractant protein-1 (MCP1) have been observed in the primary immune response to gluten in CD patients $[6,8]$. Interestingly, genetic variants within regulatory regions that can affect trancription and protein production levels, RANTES -403 G/A (rs2107538) and -28 G/C (rs2280788) and MCP-1 -2518 G/A (rs1024611) SNPs, were described [22-24].

Taking into consideration these findings, in this work we aimed to investigate the possible implication of $I L-1 \alpha, I L-$ $1 \beta, I L-1 R N, I L-18$, RANTES and MCP-1 functional polymorphisms in CD susceptibility.

\section{Methods Patients}

In the present work we have analysed a panel of 105 celiac families characterised by the presence of an affected child with $\mathrm{CD}$. The study participants were recruited at "Hospital Materno-Infantil" and "Hospital Clinico Universitario", Granda, (Spain) and were of Spanish Caucasian origin. All patients were diagnosed following the European Society of Paediatric Gastroenterology, Hepatology and Nutrition (ESPGHAN) criteria for CD [25]. Their age at study was $7.1 \pm 3.9$ years and the mean age for disease diagnosis was $2.7 \pm 2.72$. A $60 \%$ were women and $40 \%$ men, showing an anthropometry at diagnosis (weight and height) of P 3-100 percentile. The mean age of gluten introduction was $6.4 \pm 1.5$ months. Typical symptoms were observed in $72.2 \%$ of patients and $27.8 \%$ showed atypical symptoms. All family members were genotyped in DRB1 and DQB1. DQA1 typing was deduced from DQB1 and DRB1 typing on the basis of the strong linkage disequilibrium among HLA class II alleles.

\section{Genotyping}

DNA from patients and controls was obtained from peripheral blood using standard methods. For all of the considered SNPs, except IL-1RN and RANTES -403, samples were genotyped using a Taqman 5 ' allelic discrimination assay. Table 1 shows the Taqman MGB probes sequences used for each polymorphism provided by the Custom-Taqman-SNP-Genotyping-Assay (Applied Biosystems, Foster City, CA, USA). PCR reaction was carried in a total reaction volume of $5 \mu \mathrm{l}$ with the following amplification protocol: denaturation at $92^{\circ} \mathrm{C}$ for $10 \mathrm{~min}$, followed by 50 cycles of denaturation at $92^{\circ} \mathrm{C}$ for $15 \mathrm{sec}$ and annealing and extension at $58^{\circ} \mathrm{C}$ for $1 \mathrm{~min}$. Post-PCR, the genotype of each sample was attributed automatically by measuring the allelic specific fluorescence on the ABI PRIM 7900 Sequence Detection Systems using the SDS 2.2.1 software for allelic discrimination (Applied Biosystems, Foster City, CA, USA). RANTES - 403 genotyping was performed using a TaqMan SNP-Genotyping-Assay (part number: C_15874407_10, Applied Biosystems, Foster City, CA, USA).

The IL-1RN polymorphism was genotyped by PCR as previously described [26]. Briefly, we used a froward primer 5'- CTC AGC AAC ACCT CCT AT and reverse primer 5'TCC TGG TCT GCA GGT AA, two amplify five possible alleles with different PCR fragment size: 410 bp (allele 1 : 4 repeats), 240 bp (allele 2: two repeats), 325 bp (allele 3 : 3 repeats), 500 bp (allele 4: 5 repeats), and 595 bp (allele 5: 6 repeats).

\section{Statistical analysis}

We used the UNPHASED software created for TDT and case-control analysis [27]. We performed a Transmission 
Table I: Taqman probes used for cytokine genotyping

\begin{tabular}{|c|c|}
\hline Polymorphism & Taqman probe sequence \\
\hline \multirow[t]{2}{*}{ IL-IA -889 C/T (rs | 800587) } & VIC - CCTTCAATGGTGTTGCC \\
\hline & FAM - CCTTCAATGATGTTGCC \\
\hline \multirow[t]{2}{*}{ IL-IB -55 I C/T (rs I |43627) } & VIC - CTGTTTTTATGGCTTTCA \\
\hline & FAM - CTGTTTTTATAGCTTTCA \\
\hline \multirow[t]{2}{*}{ IL-I 8 -607 C/A (rs|9465 I8) } & VIC - ATCATTAGAATTTTATGTAATAAT \\
\hline & FAM - ATCATTAGAATTTTATTTAATAAT \\
\hline \multirow[t]{2}{*}{ IL-1 8 - |37 G/C (rs | 87238) } & VIC - ACTATTTTCATGAAATCTTTTCT \\
\hline & FAM - TTTTCATGAAATGTTTTCT \\
\hline \multirow[t]{2}{*}{ RANTES -28 G/C (rs2280788) } & VIC - CCCCTCAACTGGC \\
\hline & FAM - CCCCTGAACTGGC \\
\hline \multirow[t]{2}{*}{ MCP-I -25I8 G/A (rs I0246II) } & VIC - CAGACAGCTGTCACTTT \\
\hline & FAM - CAGACAGCTATCACTTT \\
\hline
\end{tabular}

Table 2: Allelic frequencies and percentage of transmission of $I L-I \alpha, I L-I \beta$, IL-IRN, IL-I8, RANTES and MCP-I genetic variants in CD families.

\begin{tabular}{|c|c|c|c|c|}
\hline & $\begin{array}{l}\text { Alelle frequency in } \\
\text { parents (\%) }\end{array}$ & $T: N T$ & $\% T$ & $P$ \\
\hline \multicolumn{5}{|c|}{ IL-IA -55 I } \\
\hline C & 70.4 & $|1|: 125$ & 47 & 0.08 \\
\hline $\mathbf{T}$ & 29.6 & $52: 38$ & 58 & 0.08 \\
\hline \multicolumn{5}{|c|}{ IL-I B -889 } \\
\hline $\mathbf{T}$ & 67.6 & $110: 111$ & 49.7 & NS \\
\hline C & 32.4 & $47: 46$ & 50.5 & NS \\
\hline \multicolumn{5}{|c|}{ IL-IRNVNTR } \\
\hline I & 71.6 & 107:107 & 50 & NS \\
\hline 2 & 26.8 & $43: 42$ & 50.6 & NS \\
\hline 3 & 1.6 & $2: 2$ & 50 & NS \\
\hline \multicolumn{5}{|c|}{ IL-1 8 -607 } \\
\hline C & 61.7 & 102:103 & 49.7 & NS \\
\hline $\mathbf{A}$ & 38.3 & $59: 58$ & 50.4 & NS \\
\hline \multicolumn{5}{|c|}{ IL- 18 - I 37} \\
\hline G & 75.9 & $124: 124$ & 50 & NS \\
\hline C & 24.1 & 47:47 & 50 & NS \\
\hline \multicolumn{5}{|c|}{ RANTES -28 } \\
\hline C & 84.1 & |55:|48 & 51 & 0.04 \\
\hline G & 15.9 & $3: 10$ & 23 & 0.04 \\
\hline \multicolumn{5}{|c|}{ RANTES -403} \\
\hline G & 85.7 & $|4|: \mid 28$ & 52 & 0.06 \\
\hline $\mathbf{A}$ & 14.3 & $23: 36$ & 39 & 0.06 \\
\hline \multicolumn{5}{|c|}{ MCP-I } \\
\hline $\mathbf{A}$ & 72.8 & $117: 129$ & 47 & NS \\
\hline G & 27.2 & $48: 36$ & 57 & NS \\
\hline
\end{tabular}

$T=$ transmitted, $N T=$ not transmitted $\% T=$ percentage transmitted

Disequilibrium Test (TDT), which assesses allele transmission rates in simplex families and tests for deviation from expected 50\% transmission. For the haplotype analysis, pair-wise linkage disequilibrium measures were investigated and haplotypes constructed using the expec- tation-maximization (EM) algorithm implemented in UNPHASED software. The power of the study to detect an effect of a polymorphism in disease susceptibility was estimated using the Quanto v 0.5 software (Department of 
Table 3: Transmission pattern of haplotypes inferred for IL- 18 and RANTES promoter genetic variant in CD families

\begin{tabular}{|c|c|c|c|c|}
\hline Gene & Haplotype & Transmitted (\%) & No transmitted (\%) & $P$ \\
\hline \multirow[t]{3}{*}{ II-18 } & $-607 A /-137 G$ & $37(24)$ & $35(22.5)$ & NS \\
\hline & $-607 A /-137 C$ & $19(12.2)$ & $20(13)$ & NS \\
\hline & $-607 C /-137 G$ & $99(63.8)$ & $100(64.5)$ & NS \\
\hline \multirow[t]{3}{*}{ RANTES } & $-403 G /-28 A$ & $3(1.4)$ & $8(5.2)$ & NS \\
\hline & $-403 \mathrm{~A} /-28 \mathrm{C}$ & $19(12.3)$ & $26(16.8)$ & NS \\
\hline & $-403 G /-28 C$ & $132(85.7)$ & $119(81.5)$ & 0.05 \\
\hline
\end{tabular}

Preventive Medicine University of Southern California, California, USA) [28].

\section{Results ILI gene cluster}

The transmission pattern for $I L-1 \alpha-889, I L-1 \beta-511$ and $I L-1 R N$ VNTR polymorphisms is shown in table 2 . When transmission of these genetic variants was analysed, none of the alleles showed statistically significant skewing. IL$1 \alpha-889 \mathrm{~T}$ allele was slightly more transmitted to the affected children (58\% transmission for allele $\mathrm{T}$ vs $47 \%$ for allele C), however the $p$ value failed to reach statistically significant level (Table 2). With regard to $I L-1 R N$ we observed that alleles IL-1RN*1 and IL-1RN*2 were the most frequent in our population $(71.6 \%$ and $26.8 \%$ respectively), accordingly with previously studies in Caucasian populations [26].

\section{IL I 8 gene}

The TDT analysis for $-607 \mathrm{~A} / \mathrm{C}$ and $-137 \mathrm{G} / \mathrm{C}$ IL-18 promoter genetic variants did not reveal biased transmission of any of the alleles to the affected offspring (Table 2).

The haplotype estimation for the $-607 \mathrm{~A} / \mathrm{C}$ and -137 IL-18 promoter variants revealed complete linkage disequilibrium between the two variants $\left(D^{\prime}=1\right)$. We observed three out of the four possible haplotypic combinations in CD families (Table 3). The transmission pattern of IL-18 promoter haplotypes did not show any statistically significant skewing (Table 3 ).

\section{MCP-I and RANTES}

After analyzing the MCP-1 -2518 G/A alleles transmission we observed that none of the alleles was preferentially transmitted from heterozygous parents to the affected offspring (Table 2). Regarding to the RANTES promoter genetic variants the mutant alleles $-403 \mathrm{~A}$ and $-28 \mathrm{G}$ showed an overall allele frequency similar to that expected for Caucasian populations $(84.1 \%$ and $96.5 \%$ respectively in our population) $[29,30]$. The transmission of both $-403 \mathrm{G} / \mathrm{A}$ and $-28 \mathrm{C} / \mathrm{G}$ SNPs showed a slightly deviation from the $50 \%$ expected transmission pattern
(Table 2). Alleles - $403 \mathrm{G}$ and -28 C were more transmitted to the affected offspring with borderline significance $(P=$ 0.04 and $P=0.06$ respectively) (Table 2 ). In addition, we estimated haplotypes for both genetic variants. Three out of the four haplotypic combinations were observed, being the $-403 \mathrm{G} /-28 \mathrm{C}$ and $-403 \mathrm{~A} /-28 \mathrm{C}$ haplotypes the most common in CD families. No significant distorted transmission pattern for RANTES promoter haplotypes was observed (Table 3 ).

\section{Discussion}

$\mathrm{CD}$ is considered a model for autoimmune disorders since many of the components that generate the altered immune response to gluten have been well characterized [1]. However, there are some relevant events of CD pathogenesis that remain unclear, for instance the stimuli that drives the high IFN $\gamma$ levels in the small intestine of $\mathrm{CD}$ patients and why only one out of 20-30 DQ2-positive individuals develops $\mathrm{CD}$ [3]. An explanation for these questions might be provided from recent studies that point out a role for the innate immunity in CD [4]. This finding supports a novel focus of research in CD molecular and genetic basis, opening a new field for the functional search of CD candidate genes.

In this work, for the first time we have assessed the relevance of $I L-1 \alpha, I L-1 \beta, I L-1 R N, I L-18, R A N T E S$ and MCP-1 genes in $\mathrm{CD}$ predisposition. All these genes have been previously associated with susceptibility to several autoimmune disorders [31-40]. However, we failed to detect an association of $I L-1 \alpha, I L-1 \beta, I L-1 R N, I L-18$, and MCP-1 genes with CD predisposition using a TDT analysis in our cohort of 105 simplex CD families. Only a borderline significant association of RANTES promoter genetic variants with $C D$ predisposition was observed.

Several studies have focused on the role of RANTES 403G/A and -28 G/C promoter polymorphisms in susceptibility to different autoimmune disorders. The RANTES 403A allele has been associated with susceptibility to multiple sclerosis (MS) and polymialgia rheumatica $[41,42]$. On the other hand, the RANTES -28G allele was observed 
to be a genetic risk for clinical complications such us diabetic neprhopathy, early onset of MS, lower levels of C3 in SLE, and higher incidence of central nervous system lupus [37,38,41]. Both RANTES $-403 \mathrm{~A}$ and $-28 \mathrm{G}$ alleles were associated with higher RANTES expression levels [22,23]. However, considering the multiple testing of the 6 different genes of our study, the association observed for RANTES promoter variants in our population can not be considered as being significant. Therefore, our results of RANTES suggest that further studies should be performed to clarify the role of RANTES in CD and autoimmune diseases in general.

Using a familial approach we eliminate the risk of population stratification derived from case-control association studies. In addition, we estimated that our study design would have considerable power to detect the effect of a polymorphism with moderate to high risk for $\mathrm{CD}$. Assuming an additive model, a minor allele frequency of 0.30 (corresponding to a median value of the majority of markers considered) and RR of 1.8 we would reach $81 \%$ power to detect an association in our population. Nevertheless, under a dominant model the power drops to $49 \%$ and considering a lower disease allele frequency, for instance 0.16 as is the case of RANTES -28, our study power would decrease to a $64 \%$ for a RR of 1.8 , and increases to $82 \%$ when we assume a RR of 2.0. For this reason, the low level of significance that our TDT analysis reached for RANTES promoter genetic variants might well reflect a true positive, and therefore needs further confirmation using a larger group of CD families.

Taking into account our findings, it is suggested that the analysed genetic polymorphisms of $I L-1 \alpha, I L 1-\beta, I L-1 R N$, IL-18, RANTES and MCP-1 genes seem not to play a major role in $\mathrm{CD}$ susceptibility in our population. It might be possible that the release of these cytokines and chemokines observed in $\mathrm{CD}$ patients could be derived from the activity of other innate immunity related pro-inflammatory mediators with higher influence in disease pathogenesis. In this regard, it is known that in CD the cytokine expression pattern in response to gluten is strongly dominated by IFN $\gamma$ [43]. Of note, in a recent work we assessed the influence of a functional dinucleotide polymorphism of IFN $\gamma$ gene in CD predisposition. An association of a higher IFN $\gamma$ producer allele with CD was observed, supporting a possible explanation for the high levels of INF $\gamma$ observed in intestinal mucosa of CD patients [44].

Other proinflammatory mediators related with innate immunity such as, TNF- $\alpha$ and IL-12, has been analysed with respect to CD susceptibility. In accordance with our findings no evidence of association was found between IL12 and CD in two independent studies $[45,46]$. Regarding TNF- $\alpha$ it has been difficult to dissect the relevance of this genetic marker in CD since it maps within HLA clas III region and it shows linkage disequilibrium with CD disease predisposing DQ2 alleles. In fact controversial results have been obtained, and there is no consensus about an independent or due to linkage disequilibrium role of TNF- $\alpha$ in CD susceptibility $[47,48]$.

\section{Conclusion}

Our results suggest that $I L-1 \alpha, I L 1-\beta, I L-1 R N, I L-18$, RANTES and MCP-1 genetic variants do not play a major role in $\mathrm{CD}$ genetic predisposition, although the suggestive evidence for RANTES deserves further investigation. Furthermore, we consider the innate response an intriguing focus of research and it should be of interest to investigate the role of other cytokines up-regulated in the early events of CD.

\section{Competing interests}

The author(s) declare that they have no competing interests.

\section{Authors' contributions}

B.R., carried out the genotyping and statistical analysis and drafted the manuscript.

A.Z., participated in the genotyping and helped in the use of the ABI PRIM 7900 Sequence Detection Systems and SDS 2.2.1 software.

M.A. L-N., collected the samples and revised the manuscript.

J.M., participated in the manuscript design and coordination and helped to draft the manuscript

B.K., reviewed the statistical analysis and helped to draft the manuscript.

All authors read and approved the final manuscript.

\section{Acknowledgements}

This work was supported by grant SAF03-460 from Plan Nacional de I+D (CICYT), and in part by Consejería de Educación, Junta de Andalucía, grupo CTS- 180 .

B.K. is supported by the Dutch Diabetes Research Foundation, The Netherlands Organisation for Health Research and Development (ZonMW) and The Juvenile Diabetes Research Foundation International (JDRF) (2001.10.004).

\section{References}

I. Sollid LM: Coeliac disease: dissecting a complex inflammatory disorder. Nature Review Immunology 2002, 2:647.

2. Louka AS, Sollid LM: HLA in coeliac disease: Unravelling the complex genetics of a complex disorder. Tissue Antigens 2003, 6I:105-117.

3. Green PH, Jabri B: Coeliac disease. Lancet 2003, 362:383-39I. 
4. Schuppan D, Esslinger B, Dieterich W: Innate immunity and coeliac disease. Lancet 2003, 362:3-4.

5. Maiuri L, Ciacci C, Ricciardelli I, Vacca L, Raia V, Auricchio S, Picard J, Osman M, Quaratino S, Londei M: Association between innate response to gliadin and activation of pathogenic $T$ cells in coeliac disease. Lancet 2003, 362:30-37.

6. Tuckova L, Novotna J, Novak P, Flegelova Z, Kveton T, Jelinkova L, Zidek Z, Man P, Tlaskalova-Hogenova H: Activation of macrophages by gliadin fragments: isolation and characterization of active peptide. J Leukoc Biol 2002, $71: 625-631$.

7. Forsberg G, Fahlgren A, Horstedt P, Hammarstrom S, Hernell O, Hammarstrom ML: Presence of bacteria and innate immunity of intestinal epithelium in childhood celiac disease. $\mathrm{Am} J$ Gastroenterol 2004, 99:894-904.

8. Chowers Y, Marsh MN, De Grandpre L, Nyberg A, Theofilopoulos AN, Kagnoff MF: Increased proinflammatory cytokine gene expression in the colonic mucosa of coeliac disease patients in the early period after gluten challenge. Clin Exp Immunol 1997, 107:141-147.

9. Fornari MC, Pedreira S, Niveloni S, Gonzalez D, Diez RA, Vazquez H, Mazure R, Sugai E, Smecuol E, Boerr L, et al:: Pre- and post-treatment serum levels of cytokines IL-I beta, IL-6, and IL-I receptor antagonist in celiac disease. Are they related to the associated osteopenia? Am J Gastroenterol 1998, 93:4I3-4I8.

10. Salvati VM, MacDonald TT, Bajaj-Elliott M, Borrelli M, Staiano A, Auricchio S, Troncone R, Monteleone G: Interleukin 18 and associated markers of $T$ helper cell type $I$ activity in coeliac disease. Gut 2002, 50:186-190.

II. Arend WP: The balance between IL-I and IL-IRa in disease. Cytokine Growth Factor Rev 2002, I 3:323-340.

12. di Giovine FS, Takhsh E, Blakemore Al, Duff GW: Single base polymorphism at $-5 \mathrm{II}$ in the human interleukin- $I$ beta gene (ILI beta). Hum Mol Genet 1992, I:450.

13. McDowell TL, Symons JA, Ploski R, Forre O, Duff GW: A genetic association between juvenile rheumatoid arthritis and a novel interleukin-I alpha polymorphism. Arthritis Rheum 1995, 38:22I-228.

14. Hall SK, Perregaux DG, Gabel CA, Woodworth T, Durham LK, Huizinga TW, Breedveld FC, Seymour AB: Correlation of polymorphic variation in the promoter region of the interleukin-I beta gene with secretion of interleukin-I beta protein. Arthritis Rheum 2004, 50:1976-1983

15. Tarlow JK, Blakemore Al, Lennard A, Solari R, Hughes HN, Steinkasserer A, Duff GW: Polymorphism in human IL-I receptor antagonist gene intron $\mathbf{2}$ is caused by variable numbers of an 86-bp tandem repeat. Hum Genet 1993, 91:403-404.

16. Witkin SS, Gerber S, Ledger W]: Influence of interleukin-I receptor antagonist gene polymorphism on disease. Clin Infect Dis 2002, 34:204-209.

17. Gracie JA, Robertson SE, McInnes IB: Interleukin- I8. J Leukoc Biol 2003, 73:213-224.

18. Eaton $A D, X u D$, Garside $P$ : Administration of exogenous interleukin- 18 and interleukin- 12 prevents the induction of oral tolerance. Immunology 2003, 108:196-203.

19. Lettesjo H, Hansson T, Bergqvist A, Gronlund J, Dannaeus A: Enhanced interleukin-18 levels in the peripheral blood of children with coeliac disease. Clin Exp Immunol 2005, 139: 138-143.

20. Tone M, Thompson SA, Tone Y, Fairchild PJ, Waldmann H: Regulation of IL- 8 (IFN-gamma-inducing factor) gene expression. J Immunol 1997, I 59:6|56-6163.

21. Giedraitis V, He B, Huang WX, Hillert J: Cloning and mutation analysis of the human IL-I 8 promoter: a possible role of polymorphisms in expression regulation. I Neuroimmunol 2001, II 2:146-I52.

22. Liu H, Chao D, Nakayama EE, Taguchi H, Goto M, Xin X, Takamatsu JK, Saito H, Ishikawa Y, Akaza T, et al.: Polymorphism in RANTES chemokine promoter affects HIV-I disease progression. Proc Natl Acad Sci U S A 1999, 96:4581-4585.

23. McDermott DH, Beecroft MJ, Kleeberger CA, Al-Sharif FM, Ollier WE, Zimmerman PA, Boatin BA, Leitman SF, Detels R, Hajeer AH, et al: Chemokine RANTES promoter polymorphism affects risk of both HIV infection and disease progression in the Multicenter AIDS Cohort Study. Aids 2000, 14:267|-2678.
24. Rovin BH, Lu L, Saxena R: A novel polymorphism in the MCP-I gene regulatory region that influences MCP-I expression. Biochem Biophys Res Commun 1999, 259:344-348.

25. Revised criteria for diagnosis of coeliac disease. Report of Working Group of European Society of Paediatric Gastroenterology and Nutrition. Arch Dis Child 1990, 65:909-I I.

26. Craggs A, West $S$, Curtis A, Welfare M, Hudson M, Donaldson P, Mansfield J: Absence of a genetic association between IL-I RN and IL-IB gene polymorphisms in ulcerative colitis and Crohn disease in multiple populations from northeast England. Scand J Gastroenterol 200I, 36: I I73-I I 78

27. Dudbridge F: Methods and software for association tests of uncertain haplotypes in case-parent trios. Am J Hum Genet 2002, 7 I (SuppIA2338 [http://portal.litbio.org/Registered/Webapp/ glue/].

28. Gauderman W]: Candidate gene association analysis for a quantitative trait, using parent-offspring trios. Genet Epidemiol 2003, 25:327-338.

29. al Sharif $\mathrm{F}$, Ollier $\mathrm{WE}$, Hajeer $\mathrm{AH}$ : A rare polymorphism at position $\mathbf{- 2 8}$ in the human RANTES promoter. Eur J Immunogenet 1999, 26:373-374.

30. Hajeer AH, al Sharif F, Ollier WE: A polymorphism at position 403 in the human RANTES promoter. Eur J Immunogenet 1999, 26:375-376.

31. Parks CG, Cooper GS, Dooley MA, Treadwell EL, St Clair EW, Gilkeson GS, Pandey JP: Systemic lupus erythematosus and genetic variation in the interleukin I gene cluster: a population based study in the southeastern United States. Ann Rheum Dis 2004, 63:91-94.

32. Timms AE, Crane AM, Sims AM, Cordell HJ, Bradbury LA, Abbott A, Coyne MR, Beynon O, Herzberg I, Duff GW, et al:: The interleukin I gene cluster contains a major susceptibility locus for ankylosing spondylitis. Am J Hum Genet 2004, 75:587-595.

33. Mann CL, Davies MB, Stevenson VL, Leary SM, Boggild MD, Ko Ko C Jones PW, Fryer AA, Strange RC, Thompson AJ, et al: Interleukin I genotypes in multiple sclerosis and relationship to disease severity. I Neuroimmunol 2002, 129:197-204.

34. Kaijzel EL, van Dongen H, Bakker AM, Breedveld FC, Huizinga TW, Verweij CL: Relationship of polymorphisms of the InterleukinI gene cluster to occurrence and severity of rheumatoid arthritis. Tissue Antigens 2002, 59:122-126.

35. Ide A, Kawasaki E, Abiru N, Sun F, Fukushima T, Ishii R, Takahashi R, Kuwahara H, Fujita N, Kita A, et al.: Association of interleukin- 18 gene promoter polymorphisms in type $I$ diabetes and autoimmune thyroid disease. Ann N Y Acad Sci 2003, 1005:436-439.

36. Novota P, Kolostova K, Pinterova D, Novak J, Treslova L, Andel M, Cerna M: Interleukin IL- 18 gene promoter polymorphisms in adult patients with type I diabetes mellitus and latent autoimmune diabetes in adults. Immunol Lett 2005, 96:247-25 I

37. Nakajima K, Tanaka $Y$, Nomiyama T, Ogihara T, lkeda F, Kanno R, Iwashita N, Sakai K, Watada H, Onuma T, et al.: RANTES promoter genotype is associated with diabetic nephropathy in type 2 diabetic subjects. Diabetes Care 2003, 26:892-898.

38. Liao CH, Yao TC, Chung HT, See LC, Kuo ML, Huang JL: Polymorphisms in the promoter region of RANTES and the regulatory region of monocyte chemoattractant protein-I among Chinese children with systemic lupus erythematosus. Rheumatol 2004, 31:2062-2067.

39. Tucci M, Barnes EV, Sobel ES, Croker BP, Segal MS, Reeves WH, Richards HB: Strong association of a functional polymorphism in the monocyte chemoattractant protein I promoter gene with lupus nephritis. Arthritis Rheum 2004, 50:1842-1849.

40. Kim HL, Lee DS, Yang SH, Lim CS, Chung JH, Kim S, Lee JS, Kim YS The polymorphism of monocyte chemoattractant protein-I is associated with the renal disease of SLE. Am J Kidney Dis 2002, 40: II46-1152.

4I. Gade-Andavolu R, Comings DE, MacMurray J, Vuthoori RK, Tourtellotte WW, Nagra RM, Cone LA: RANTES: a genetic risk marker for multiple sclerosis. Mult Scler 2004, 10:536-539.

42. Makki RF, al Sharif F, Gonzalez-Gay MA, Garcia-Porrua C, Ollier WE, Hajeer AH: RANTES gene polymorphism in polymyalgia rheumatica, giant cell arteritis and rheumatoid arthritis. Clin Exp Rheumatol 2000, 18:391-393.

43. Nilsen EM, Jahnsen FL, Lundin KE, Johansen FE, Fausa O, Sollid LM, Jahnsen J, Scott H, Brandtzaeg P: Gluten induces an intestinal 
cytokine response strongly dominated by interferon gamma in patients with celiac disease. Gastroenterology 1998, I 15:55I-563.

44. Rueda B, Martinez A, Lopez-Nevot MA, Mas-Fontao A, Paco L, Ortega E, Fernandez-Arquero M, Urcelay E, Gomez de la Concha E, Martin J: A functional variant of IFNgamma gene is associated with coeliac disease. Genes Immun 2004, 5:517-519.

45. Louka AS, Torinsson Naluai A, D'Alfonso S, Ascher $\mathrm{H}$, Coto I, Ek J, Giordano M, Gudjonsdottir AH, Mellai M, Momigliano-Richiardi P, et al.: The ILI 2B gene does not confer susceptibility to coeliac disease. Tissue Antigens 2002, 59:70-72.

46. Seegers D, Borm ME, van Belzen MJ, Mulder CJ, Bailing J, Crusius JB, Meijer JW, Wijmenga C, Pena AS, Bouma G: ILI 2B and IRFI gene polymorphisms and susceptibility to celiac disease. Eur J Immunogenet 2003, 30:42I-425.

47. de la Concha EG, Fernandez-Arquero M, Vigil P, Rubio A, Maluenda C, Polanco I, Fernandez C, Figueredo MA: Celiac disease and TNF promoter polymorphisms. Hum Immunol 2000, 6 I:5 I3-5 I7.

48. Woolley N, Mustalahti K, Maki M, Partanen J: Cytokine gene polymorphisms and genetic association with coeliac disease in the Finnish population. Scand J Immunol 2005, 6 I:5 I-56.

\section{Pre-publication history}

The pre-publication history for this paper can be accessed here:

http://www.biomedcentral.com/1471-2350/6/29/prepub

Publish with Bio Med Central and every scientist can read your work free of charge

"BioMed Central will be the most significant development for disseminating the results of biomedical research in our lifetime. "

Sir Paul Nurse, Cancer Research UK

Your research papers will be:

- available free of charge to the entire biomedical community

- peer reviewed and published immediately upon acceptance

- cited in PubMed and archived on PubMed Central

- yours - you keep the copyright

Submit your manuscript here:

http://www.biomedcentral.com/info/publishing_adv.asp 